\title{
The Effect of Perineal Massage on Perineal Tear Case on Primigravida Pregnant Mothers In Their Third Trimester In Public Health Center Care of Morokay 2018
}

\author{
Triana Indrayani*, Nurabia Tuasikal \\ National University, Jakarta, Indonesia \\ *trianaindrayani@civitas.unas.ac.id
}

\begin{abstract}
The National Hospital Discharge Survey reported that in the United States of the 26 million mothers giving birth, there were $40 \%$ mothers experiencing perineal tear (NHDS, 2014). Perineal tear is one of the complications of second stage labor which can cause dysfunction of the female reproductive organs, bleeding and lacerations. The prevalence of maternal births that have perineal tear in primigravida was $69.8 \%$ and was one of the causes of increased morbidity in pregnant women. Some efforts can be made to reduce the risk of spontaneous perineal tear, one of the effort is perineal massage.

This research aimed to find out the effect of perineal massage on the perineal tear in primigravida pregnant women trimester III in Morokay Public Health Center in 2018.

The research used a Quasi-experimental design. The sampling technique used purposive random sampling. The sample was obtained by 32 respondents divided into 2 groups, 16 respondents were given perineal massage and 16 respondents were not given perineal massage.The data were analyzed using Mann Whitney Test.

The results showed that there were differences of perineal tear in experimental group and the control group with a p-value (0.005).

There was a difference in the incidence of perineal tear between groups carried out perineal massage and those with no perineal massage. Perineal massage can reduce the risk of perineal tear. It is important to be informed and applied that massage is one of the non-pharmacological interventions to prevent perineal rupture.
\end{abstract}

Keywords : Perineal Massage, Perineal Tear, Primigravida. 


\section{STRADA Jurnal Ilmiah Kesehatan}

DOI: $10.30994 /$ sjik.v9i2.346

ISSN: 2252-3847 (print); 2614-350X (online)

Vol.9 No.2 November 2020 Page.588-592

\section{BACKGROUND}

Labor is a physiological process for woman. Labor process is the release of fullterm conception result (fetus and placenta) or can live outside by giving birth, with or without assistance (own strength). Perineum is one of the paths passed that can be torn due to the labor process or cut purposively to widen the baby's way out (episiotomy).(Oktavina, Sulistyowati, Triestuning, \& Annisa, 2020; Prahayu, 2017)

Perineal tear case in Asia is quite often to be found, in which $50 \%$ of total perineal tear cases happened in the world is from Asia (Nasution). The prevalence of mothers suffering from perineal tear in Indonesia at the age range of 25-30 years old is 62\%, at the age range of $32-39$ is $24 \%$, at primigravida mothers is $69.8 \%$, multigravida mothers is $16.7 \%$ and grandemultigravida mothers is $13.5 \%$ (Sutra Nurjanna \& Isra, 2017)

The Health Office of Maluku reported that Maternal Mortality Rate (MMR) in Maluku Province based on the report issued by district/city is 101/100.000 live birth. The MMR is caused by bleeding (42\%), preeclampsia/eclampsia (13\%), abortion (11\%), infection (10\%), the partition takes long time or stuck $(9 \%)$ and others. It was also obtained that perineal tear suffered by primigravida mothers in Central Maluku District is still high which is 13\% (Luthfiyah, 2014).

The common cause of perineal tear is precipitous parturition, too strong straining, edema, fragile perineum, flexibility in birth canal, and labor action (Luthfiyah, 2014). One of the efforts that can be done to prevent perineal tear during giving birth is perineal massage. Perineal massage is a technique in massaging perineum during pregnancy or weeks before giving birth in order to increase the blood flow or perineum elasticity. The increase of perineum elasticity can prevent perineal tear or episiotomy (Rochmayanti, Ummah, \& Keb, 2019).

Previous research on Antenatal Perineal Massage for Reducing Perineal Trauma conducted by Backmann (2013) stated that perineal massage done during the pregnancy age of 35 weeks can decrease perineal tear or episiotomy cases.(Beckmann \& Garrett, 2006)

Research conducted by dr. Richard Johnson, MRCOG Obstetrician from North Staffordshire Maternity Hospital in England found that mothers who obtained perineal massage at 3-4 weeks before the D-day are proven to almost do not need episiotomy action. According to the research conducted by Ommolbabin (2014), it was stated that risk of perineal laceration on mothers who obtained massage is lower that mothers who did not get the massage, which means that perineal massage affected the perineal laceration case.

Another research project conducted by Dartiwen (2015) in Banyuwangi found that perineal massage on primigravida mothers can decrease laceration case. Similar result also reported by Wewet Savitri (2014) that massage on primigravida mothers affected the perineal tear case during labor process (Dartiwen \& Sabri, 2015)

Preliminary study conducted in Public Health Center Care of Morokay in September 2018 found that among 18 primigravida mothers, 9 of them suffered from perineal tear $(55 \%)$ which then increased in October 2018, in which among 20 primigravida mothers, 13 of them suffered from perineal tear $(65 \%)$.

Based on the data above, the researchers of the current research was interested in conducting research on the effect of perineal massage on perineal tear case on primigravida pregnant mothers in their third trimester in Public Health Center Case of Morokay 2018. 


\section{STRADA Jurnal Ilmiah Kesehatan}

DOI: $10.30994 /$ sjik.v9i2.346

ISSN: 2252-3847 (print); 2614-350X (online)

Vol.9 No.2 November 2020 Page.588-592

\section{METHOD}

The method applied in the current research was Quasi-Experimental research, in which the population was pregnant mothers in their third trimester in December 2018-January 2019. The samples used were by estimating the labor in December 2018-January 2019 which was 32 mothers.

\section{RESULT}

Table 4.1. The Distribution of Perineal Tear Case Frequency on Primigravida Mothers from the Experimental Group in Public Health Center Care of Morokay 2018

\begin{tabular}{lll}
\hline Perineal Tear & $\mathrm{f}$ & $\%$ \\
\hline Perineal Tear occurred & 5 & $31.2 \%$ \\
Perineal Tear did not occur & 11 & $68.8 \%$ \\
Total & 16 & $100 \%$ \\
\hline
\end{tabular}

Based on table 4.1 above, among 16 research respondents, there were 5 mothers (31.2\%) who suffered from perineal tear, while the remaining 11 mothers $(68.8 \%)$ did not suffer from perineal tear.

Table 4.2. The Distribution of Perineal Tear Case Frequency on Primigravida Mothers from the Control Group in Public Health Center Care of Morokay 2018

\begin{tabular}{lll}
\hline Perineal Tear & f & $\%$ \\
\hline Perineal Tear occurred & 13 & $81.2 \%$ \\
Perineal Tear did not occur & 3 & $18.8 \%$ \\
Total & 16 & $100 \%$ \\
\hline
\end{tabular}

Based on table 4.2 above, among 16 research respondents, it was obtained that respondents who did not obtain perineal massage and suffered from perineal tear was as many as 13 mothers $(81.2 \%)$, while those who did not suffer from the perineal tear was 3 mothers $(18.8 \%)$.

The Effect of Perineal Massage on Perineal Tear on Primigravida Pregnant Mothers in Their Third Trimester

\begin{tabular}{llll}
\hline Group & Mean Rank & $p$ & $n$ \\
\hline Experimental & 1.174 & 0.005 & 16 \\
Control & 0.966 & & 16 \\
\hline
\end{tabular}

Based on table 1 of the statistical test using Mann Whitney test, it was obtained that there was difference in the Mean Rank value of perineal tear case between the experimental group (1.17) and control group (0.9). The statistical test obtained $\mathrm{p}=0.005$, which means that there was different perineal tear case between the experimental and control group.

\section{DISCUSSION}

The Effect of Perineal Massage on Perineal Tear Case on Primigravida Pregnant Mothers in Their Third Trimester. 


\section{STRADA Jurnal Ilmiah Kesehatan}

DOI: $10.30994 /$ sjik.v9i2.346

ISSN: 2252-3847 (print); 2614-350X (online)

Vol.9 No.2 November 2020 Page.588-592

Current research obtained that $78.6 \%$ of those who obtained perineal massage did not suffer from perineal tear and $72.2 \%$ of those who did not obtain perineal massage suffered from perineum tear. The Mann Whitney Test obtained that there was different Mean Rank difference of perineal tear between the experimental group (1.17) and control group (0.9). The statistical test also obtained $\mathrm{p}=0.005$ which means that there was perineal tear case difference between the group which obtained perineal massage and the group which did not obtained perineal massage. Perineal massage helps to soften the perineal tissue so that it will open without resistance during the labor process, in order to make it easier for the baby to be released. Perineal massage allows labor to be performed with perineum stays intact, avoid episiotomy case or torn perineum during the labor by increasing the perineum elasticity (DINA HERDIANA, 2018).

Therefore Mongan ( 2013) pregnant mothers are suggested to obtain perineal massage on the last six pregnancy weeks, because the more often it is done, the better it will be. In addition, the service quality in the community, particularly on basic service facility such as Integrated Service Post (Posyandu) or Public Health Service shall improve their health workers' skill during giving pregnancy counselling and teaching how to do perineal massage so that it can decrease the number of torn perineum case during labor process (VITRISIA, 2017)

Several previous research projects also gave similar result with this research. Research that was conducted by Beckmann and Garrett (2006), stated that perineal massage decreased the risk of suturing trauma and decreased the number of episiotomy case with OR value of 0.05 . In terms of mothers who have ever given birth claimed that they were satisfied and it did decrease the pain of perineum in 3 months post-partum with OR value of 0.03.(Beckmann \& Garrett, 2006)

Research that was done by Dartiwen (2015) regarding perineal massage on primigravida on perineal laceration during labor in independent midwifery practice in the working area of Margadadi Public Health Center of Indramayu District, it obtained that there was significant different between the mothers who obtained perineal massage and mothers who did not obtain perineal massage on perineal laceration case during labor with p-value of 0.002 and $\mathrm{OR}=11.227$.

Research that was conducted by Natami (2015) regarding the effect of perineal massage on perineal tear rate on primigravida mothers in Indonesian Statistics of Widjayati and Desak of Negara Sub-District obtained the result that there was effect of perineal massage on perineal tear rate with $\mathrm{p}=$ value of 0.005 and $\mathrm{OR}=9.454$ (Anggraini \& Anggasari, 2019).

\section{CONCLUSION}

Based on the research that was conducted, it obtained result that there was Effect of Perineal Massage on Perineum Tear Case on Primigravida Pregnant Mothers in Their Third Trimester in Public Health Service Care of Morokay 2018 including:

Respondents who did not suffer from perineal tear were 11 mothers $(68.8 \%)$ on the group which obtained perineal massage.

Respondents who suffered from perineal tear were 13 mothers $(81.2 \%)$ on the group which did not obtain perineal massage.

There was difference in perineal tear case between the group which obtained perineal massage and group which did not obtain perineal massage $(\mathrm{p}=.005)$. 


\section{STRADA Jurnal Ilmiah Kesehatan}

DOI: $10.30994 /$ sjik.v9i2.346

ISSN: 2252-3847 (print); 2614-350X (online)

Vol.9 No.2 November 2020 Page.588-592

REFERENCES

Anggraini, F. D., \& Anggasari, Y. (2019). Pengaruh Pijat Perineum Pada Kehamilan Trimester III Terhadap Robekan Perineum Primigravida Di Puskesmas Jagir Surabaya. Jurnal Ilmiah Kebidanan, 5(1).

Beckmann, M. M., \& Garrett, A. J. (2006). Antenatal perineal massage for reducing perineal trauma. Cochrane Database of Systematic Reviews(1).

Dartiwen, K., \& Sabri, L. (2015). Pengaruh Pemijatan Perineum Pada Primigravida Terhadap Kejadian Laserasi Perineum Saat Persalinan di Bidan Praktik Mandiri (BPM) Wilayah Kerja Puskesmas Margadadi Kabupaten Indramayu Tahun 2015. Jurnal Stikesmuhla, 8(02).

DINA HERDIANA, D. H. (2018). Asuhan Kebidanan Komprehensif Pada Ny " $M$ " Di Bpm D Di Bukit Tinggi Tanggal 9 Februari-21 Maret tahun 2018. Stikes Perintis Padang.

Luthfiyah, N. (2014). Determinan Pemanfaatan Pelayanan Nifas di Daerah Rural Indonesia Tahun 2011-2012.

Nasution, S. S. Asuhan Keperawatan pada Ibu Hamil Resiko Tinggi: HIV-AIDS dengan Melibatkan Masyarakat.

Oktavina, S. M., Sulistyowati, A., Triestuning, E., \& Annisa, F. (2020). ASUHAN KEPERAWATAN PADA NY. M DENGAN DIAGNOSA MEDIS PERSALINAN NORMAL DI RUANG VK RSUD BANGIL PASURUAN. Akademi Keperawatan Kerta Cendekia Sidoarjo.

Prahayu, T. (2017). Manajemen Asuhan Kebidanan Ibu Nifas pada Ny "M" dengan Luka Episiotomi di RSUD Syech Yusuf Gowa Tahun 2017. Universitas Islam Negeri Alauddin Makassar.

Rochmayanti, S. N., Ummah, K., \& Keb, A. (2019). PIJAT PERINEUM SELAMA MASA KEHAMILAN TERHADAP KEJADIAN RUPTURE PERINEUM SPONTAN: Jakad Media Publishing.

Sutra Nurjanna, P., \& Isra, W. A. (2017). IDENTIFIKASI IBU BERSALIN YANG MENGALAMI RUPTUR PERINEUM DI RUMAH SAKIT UMUM DEWI SARTIKA PROVINSI SULAWESI TENGGARA TAHUN 2016. Poltekkes Kemenkes Kendari.

VITRISIA, M. (2017). PENERAPAN PIJAT PERINEUM UNTUK MENGURANGI RUPTUR PERINEUM SAAT PERSALINAN DI KLINIK PRATAMA PERMATA IBU TERSOBO, PREMBUN. STIKES MUHAMMADIYAH GOMBONG. 